\title{
The present problems of plant protection in Poland Part II. Legislation, forecasting and pest registration, advisory service in plant protection, control of the practical application of plant protection
}

\author{
Aktualne problemy ochrony roślin w Polsce \\ Część II. Ustawodawstwo, rejestracja, sygnalizacja \\ i prognozowanie pojawu agrofagów, \\ doradztwo w zakresie ochrony roślin, \\ nadzorowanie realizacji ochrony roślin
}

\author{
Adam Błochowiak ${ }^{1}$, Stefan Pruszyński ${ }^{2}$
}

\begin{abstract}
Summary
The most important issues of plant protection in Poland in the field of legislation, forecosting and pest registration advisory service in plant protection and the control of practical application of plant protection that need an urgent solution are: development of new law regulations on plant protection as well as the National Action Plan, urgent dissemination of recent training for advisory services to fulfill their advisory role in the introduction and implementation of IPP on wider scale, maintenance and development of well organized registration, warning systems and forecasting of noxious agrophages, providing staff salary and the possibility for improvement of qualifications by the workers of Plant Health and Seed Inspection.
\end{abstract}

Key words: Poland, plant protection, legislation, forecasting and pest registration, advisory service in plant protection National Plant Protection and Seed Inspection

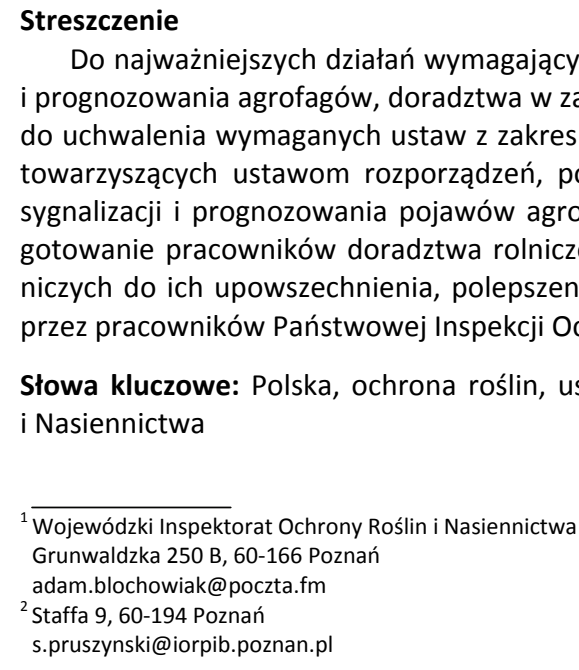
i Nasiennictwa

\footnotetext{
Wojewódzki Inspektorat Ochrony Roślin i Nasiennictwa Grunwaldzka 250 B, 60-166 Poznań

adam.blochowiak@poczta.fm

${ }^{2}$ Staffa 9, 60-194 Poznań

s.pruszynski@iorpib.poznan.pl
}

Do najważniejszych działań wymagających podjęcia w ochronie roślin w Polsce w zakresie ustawodawstwa, rejestracji, sygnalizacji i prognozowania agrofagów, doradztwa w zakresie ochrony roślin oraz nadzoru realizacji ochrony roślin należy zaliczyć: doprowadzenie do uchwalenia wymaganych ustaw z zakresu ochrony roślin, zatwierdzenie przez Rząd Krajowego Planu Działania oraz wprowadzenie towarzyszących ustawom rozporządzeń, podjęcie ostatecznych decyzji co do podporządkowania i organizacji systemu rejestracji, sygnalizacji i prognozowania pojawów agrofagów wraz z zapewnieniem warunków dalszego rozwoju, pilne podjęcie szkoleń i przygotowanie pracowników doradztwa rolniczego do wdrożenia zasad integrowanej ochrony roślin oraz producentów rolnych i ogrodniczych do ich upowszechnienia, polepszenie warunków płacowych oraz zabezpieczenie możliwości stałego podnoszenia kwalifikacji przez pracowników Państwowej Inspekcji Ochrony Roślin i Nasiennictwa.

Słowa kluczowe: Polska, ochrona roślin, ustawodawstwo, monitoring agrofagów, doradztwo, Państwowa Inspekcja Ochrony Roślin 


\section{Wstęp / Introduction}

Pierwsza część opracowania była poświęcona krótkiemu omówieniu historii rozwoju ochrony roślin w Polsce po II Wojnie Światowej, rozwojowi badań naukowych oraz edukacji. Podkreślono potrzebę zwiększania nakładów na badania naukowe, dążenie do ich skoordynowania, a także do ustalenia dużych programów badawczych z udziałem większej liczby jednostek. Zwrócono uwagę na konieczność zmiany w programach nauczania na wszystkich poziomach szkolnictwa rolniczego i zwiększenia liczby godzin zajęć $\mathrm{z}$ przedmiotów poświęconych ochronie roślin, tak, aby przygotowywać kadry do pracy w Inspekcji Ochrony Roślin i Nasiennictwa, doradztwie $\mathrm{i}$ produkcji rolniczej - zdolne do wdrażania i upowszechniania ochrony roślin.

Obecna część opracowania w większym stopniu jest poświęcona zagadnieniom związanym z realizacją zadań i praktyką ochrony roślin i obejmuje: ustawodawstwo, monitoring agrofagów, doradztwo w zakresie ochrony roślin oraz nadzorowanie ochrony roślin. Również w odniesieniu do tych obszarów ochrony roślin pozostaje wiele do zrobienia, a podejmowane decyzje będą warunkowały rozwój integrowanej ochrony roślin w naszym kraju.

\section{Ustawodawstwo / Legislation}

W Polsce pomimo wcześniej podjętych działań i przygotowania projektów wystąpiły opóźnienia w uchwaleniu aktów prawnych implementujących do polskiego ustawodawstwa akty prawne Unii Europejskiej i dopiero w listopadzie 2012 roku projekt pierwszej ustawy został skierowany do Sejmu.

Decyzją Ministerstwa Rolnictwa i Rozwoju Wsi przewidziano $\mathrm{w}$ miejsce obowiązującej aktualnie Ustawy o ochronie roślin z 2003 roku wprowadzenie dwu oddzielnych Ustaw:

- Ustawy o środkach ochrony roślin, która wprowadzi do polskiego ustawodawstwa przepisy rozporządzenia 1107/2009 oraz Dyrektywy 2009/128/WE i regulować będzie sprawy związane $\mathrm{z}$ dopuszczeniem do obrotu i stosowaniem środków ochrony roślin. Bardzo ważnym zapisem tej Ustawy będzie delegacja do przyjęcia jako dokumentu Rządowego Krajowego Planu Działania,

- Ustawy o ochronie roślin, która wdroży postanowienie Dyrektywy 2000/29/WE z dnia 8 maja 2000 roku w sprawie środków ochronnych przed wprowadzeniem do Wspólnoty organizmów szkodliwych dla roślin lub produktów roślinnych i przed ich rozprzestrzenianiem się we Wspólnocie.

Trzecim dokumentem, wymagającym przyjęcia przez Rząd jest Krajowy Plan Działania opisujący sposób wdrożenia i upowszechnienia postanowień Dyrektywy 2009/128/WE dotyczących:

- systemu szkoleń,

- podnoszenia świadomości ogółu społeczeństwa,

- zapewnienia nadzoru nad stanem technicznym sprzętu do ochrony roślin,

- ochrony środowiska wodnego i wody pitnej,
- ograniczenia stosowania środków ochrony roślin,

- wdrożenia zasad integrowanej ochrony roślin,

- monitorowania ryzyka związanego ze stosowaniem środków ochrony roślin.

Krajowy Plan Działania określi:

- cele do spełnienia w zakresie zrównoważonego stosowania środków ochrony roślin,

- działania, jakie powinny być podjęte dla osiągnięcia tych celów,

- harmonogram realizacji tych działań,

- monitoring osiagnięcia wyznaczonych celów, ocenę ryzyka oraz sposób udostępniania wyników oceny tego ryzyka opinii publicznej.

W programie 52. Sesji Naukowej Instytutu Ochrony Roślin - Państwowego Instytutu Badawczego znalazło się omówienie:

- Ustawy o środkach ochrony roślin, której projekt został opublikowany na stronie internetowej Ministerstwa Rolnictwa i Rozwoju Wsi,

- Krajowego Planu Działania oraz konsekwencji wdrożenia nowych regulacji prawnych w ochronie roślin w Polsce (Rzeźnicki 2012).

Obydwa dokumenty wejdą w życie w pierwszym kwartale 2013 roku i będą stanowić podstawę działań w zakresie ochrony roślin w Polsce na najbliższe lata.

\section{Rejestracja, sygnalizacja i prognozowanie pojawu agrofagów / Forecasting and pest registration}

Rejestrowanie pojawu i nasilenia organizmów szkodliwych, sygnalizowanie sytuacji fitosanitarnej oraz prognozowanie ich pojawu stanowią podstawę współczesnej ochrony roślin i są niezbędnym do spełnienia warunkiem we wdrażaniu integrowanej ochrony roślin. Jednocześnie informacje o pojawie i nasileniu agrofagów mogą służyć do analizy zmian klimatycznych oraz wpływu nowych technologii uprawy na rozwój agrofagów.

Znaczenie rejestracji i sygnalizacji wyraźnie podkreśla p. 2. Załącznika III Dyrektywy 2009/128/WE „Ogólne zasady integrowanej ochrony roślin”, w którym czytamy: „Organizmy szkodliwe muszą być monitorowane przy zastosowaniu odpowiednich metod i narzędzi, jeśli są one dostępne. Wśród takich narzędzi powinny znaleźć się monitoring pól oraz systemy ostrzegania, prognozowania i wczesnego diagnozowania oparte na solidnych podstawach naukowych tam, gdzie możliwe jest ich zastosowanie, a także doradztwo osób o odpowiednich kwalifikacjach zawodowych".

Analizując przygotowanie polskiej ochrony roślin do realizacji tego zadania, uwage zwraca brak jednolitego i stabilnego rozwoju tych działań, a szczególnie dotyczy to obecnej sytuacji.

W Polsce do roku 1995 obserwacje nad występowaniem ważniejszych organizmów szkodliwych prowadzili pracownicy Stacji Kwarantanny i Ochrony Roślin, a wyniki obserwacji były opracowywane w Instytucie Ochrony Roślin i przekazywane na teren całego kraju przez Komunikaty Sygnalizacyjne oraz opracowania roczne (Piekarczyk 1961). 
Po roku 1995 na mocy Ustawy o ochronie roślin uprawnych powołana została Państwowa Inspekcja Ochrony Roślin, która kontrolowała ocenę zagrożenia upraw przez organizmy nie podlegające obowiązkowi zwalczania, a dane $\mathrm{z}$ obserwacji trafiły do Instytutu Ochrony Roślin. Sytuacja ta uległa zmianie w latach 2004 2005, kiedy to Instytut Ochrony Roślin nie otrzymywał danych z Inspekcji i nie opracowywał rocznej oceny. Uchwalenie Programu Wieloletniego (2006-2010), w którym znalazły się zadania obejmujące ogólnokrajowy monitoring organizmów szkodliwych pozwoliły na wznowienie i realizację współpracy pomiędzy Inspekcją i Instytutem Ochrony Roślin (Walczak i wsp. 2011).

Wracając do obecnej sytuacji i przewidywanego wdrożenia integrowanej ochrony roślin należy dostrzegać potrzebę rozwiązania pewnych problemów, jak i potrzebę podjęcia decyzji co do funkcjonowania całego systemu w przyszłości (Pruszyński i Walczak 2010).

Przede wszystkim należy przyspieszyć prace nad opracowaniem i wdrożeniem Systemów Wspomagających Decyzję o potrzebie wykonania zabiegu dla głównych agrofagów. Systemy te oparte na znajomości biologii i ekologii organizmu szkodliwego oraz poparte wynikami obserwacji meteorologicznych powinny stanowić podstawę do podejmowania decyzji o podjęciu działań ochronnych. Działania te należy uznać za priorytetowe i zwiększyć należy dostępność producentów rolnych do Internetu, aby użytkownicy mogli na bieżąco śledzić wyniki obserwacji prowadzonych przez instytuty badawcze i Inspekcję Ochrony Roślin i Nasiennictwa.

Zachęcać też należy do rozwijania własnych inicjatyw, w tym przez producentów czy dystrybutorów w tworzeniu własnych punktów obserwacji i informowania odbiorców o sytuacji fitosanitarnej. Dobrym przykładem jest tu Zakład Zaopatrzenia Rolniczego „Warka” współpracujący z Instytutem Ogrodnictwa oraz firmą holenderska, prowadzący monitoring stanu fitosanitarnego i przekazujący informacje i zalecenia sadownikom.

W Instytucie Warzywnictwa (obecnie Instytut Ogrodnictwa) uruchamiany jest system „Integrowana ochrona pomidorów”, cieszący się dużą popularnością wśród ogrodników.

Instytut Ochrony Roślin - Państwowy Instytut Badawczy na stronie internetowej wprowadził serwis informacyjny „Sygnalizacja Agrofagów”, w którym zainteresowani mogą znaleźć informację o występowaniu i nasileniu agrofagów w punktach prowadzenia obserwacji przez Instytut.

Dalsze rozważania są już jednak znacznie mniej optymistyczne. W uchwalonym i realizowanym obecnie przez Instytut Ochrony Roślin - Państwowy Instytut Badawczy Programie Wieloletnim wykreślono zadanie: „Ocena stanu fitosanitarnego i znaczenia gospodarczego najważniejszych agrofagów oraz sugestie prognozowe". Oznacza to, że Instytut przestanie opracowywać i przekazywać do powszechnego użytku „Stan Fitosanitarny”.

$\mathrm{Za}$ bardzo poważne zagrożenie należy uznać brak ostatecznej decyzji co do organizacji, która po wejściu w życie Ustawy o ochronie roślin będzie odpowiedzialna za monitoring występowania organizmów szkodliwych.
Coraz częściej mówi się o przejęciu tego obowiązku przez służby doradcze (państwowe lub prywatne) i samych producentów rolnych. Każdy system może okazać się słusznym, $\mathrm{z}$ tym, że $\mathrm{w}$ tym przypadku należało już wcześniej podjąć przygotowanie przyszłych wykonawców do wykonywania nowych obowiązków. Zaistnieje potrzeba zakupu i wyposażenia tych jednostek w wymagany sprzęt. To wszystko będzie wymagało wiele czasu, a do obowiązkowego wprowadzenia integrowanej ochrony roślin pozostało już mniej niż dwa lata.

Prawidłowa organizacja i funkcjonowanie systemu rejestracji i prognozowania pojawu agrofagów połączona $\mathrm{z}$ oceną nasilenia występowania będzie tak, jak napisano wcześniej, podstawą integrowanej ochrony roślin i przyszłej ochrony roślin w ogóle.

\section{Doradztwo w zakresie ochrony roślin Advisory service in plant protection}

Podkreślony wcześniej dynamiczny rozwój ochrony roślin, zagrożenie dla ludzi i środowiska, jakie może towarzyszyć nieprawidłowo wykonanym zabiegom ochroniarskim, a także znaczenie ochrony roślin dla uzyskiwania wysokich i dobrych jakościowo plonów na bardzo ważnym miejscu stawia doradztwo na rzecz producentów rolnych prowadzone przez pracowników doradztwa rolniczego, ale także personelu producentów środków ochrony roślin, ich dystrybutorów czy pracowników służb plantatorskich.

W Polsce do roku 1995 podstawowe funkcje doradcze w zakresie ochrony roślin pełnili pracownicy Stacji Kwarantanny i Ochrony Roślin oraz pracownicy instytutów resortowych. Ustawa z 1995 roku, na mocy której została utworzona Państwowa Inspekcja Ochrony Roślin (od 2002 roku i Nasiennictwa) zmieniła ten stan, nakładając na pracowników Inspekcji nadzór nad ochroną roślin i jednocześnie przenosząc obowiązki doradcze na pracowników doradztwa rolniczego.

Ci ostatni byli do tych zadań nieprzygotowani, co doprowadziło do wytworzenia się ,luki”, którą tylko częściowo mogli wypełnić przedstawiciele producentów i dystrybutorów środków ochrony roślin oraz służby plantacyjne. Nie można przy tym umniejszać znaczenia działalności tych grup doradczych, które niezależnie od komercyjnej formy doradztwa spełniają ważną rolę w doradztwie technologicznym.

Pewne funkcje spełniają nadal pracownicy Inspekcji Ochrony Roślin i Nasiennictwa, do których „zwyczajowo” trafiają producenci, a także bardzo znacznie zwiększyli swą aktywność w tym obszarze pracownicy instytutów badawczych oraz szkolnictwa wyższego.

Znacznie gorzej przedstawia się sytuacja w odniesieniu do doradztwa rolniczego. Pomimo upływu już ponad 25 lat bardzo mało jest przykładów aktywnego podejścia do przygotowania się Ośrodków Doradztwa Rolniczego do podjęcia obowiązków pełnienia funkcji doradczych w zakresie ochrony roślin.

Bardzo pozytywnym wyjątkiem jest tu Wielkopolski Ośrodek Doradztwa Rolniczego (WODR), który od wielu lat prowadzi szkolenia $\mathrm{w}$ zakresie ochrony oraz przygo- 
towuje grupę doradców specjalizujących się w ochronie roślin. Z podejmowanych przez WODR w Poznaniu inicjatyw należy wymienić (na podstawie informacji uzyskanej z WODR) m.in.:

- szkolenie specjalistów doradztwa z zakresu ochrony roślin,

- wdrażanie i upowszechnianie systemów wspomagania decyzji o potrzebie podjęcia zabiegów,

- informowanie na portalu internetowym o koniecznych zabiegach ochrony roślin,

- upowszechnianie zasad integrowanej ochrony roślin.

Tak ukierunkowana działalność WODR w Poznaniu powinna być przykładem dla innych ośrodków, a wprowadzenie integrowanej ochrony roślin narzuca konieczność pilnego przeprowadzenia ogólnokrajowych szkoleń.

\section{Nadzorowanie realizacji ochrony roślin Control of the practical application of plant protection}

Jak już wcześniej wspomniano, ustawą o ochronie roślin z 1995 r., wykorzystując majątek i kadrę Wojewódzkich Stacji Kwarantanny i Ochrony Roślin, powołano do życia Państwową Inspekcję Ochrony Roślin, przekształconą następnie (2002 r.) w Państwową Inspekcję Ochrony Roślin i Nasiennictwa (PIORiN), jako urząd administracji rządowej. Zadaniem tego urzędu jest między innymi nadzór nad szeroko pojętym zdrowiem roślin oraz zapobieganie zagrożeniom, jakie może wywołać obrót i stosowanie środków ochrony roślin. Obecnie Inspekcja merytorycznie podporządkowana jest centralnemu organowi administracji rządowej, jakim jest Główny Inspektor Ochrony Roślin i Nasiennictwa, który posiada ustawową delegację upoważniającą do wydawania wiążących wytycznych i poleceń, dotyczących rodzaju i rozmiaru zadań realizowanych przez wojewódzkich inspektorów ochrony roślin i nasiennictwa. Finansowanie działalności wojewódzkich inspektoratów jako administracji zespolonej w województwie, odbywa się $\mathrm{z}$ budżetu wojewody. Ustawodawca przez takie podporządkowanie urzędów administracji odpowiedzialnej za nadzorowanie ochrony roślin, spowodował poważne problemy w zarządzaniu publicznymi środkami, przeznaczonymi na realizację ustawowych zadań należących do kompetencji Inspekcji. Jest oczywiste, że ten organ władzy rządowej, posiadający kompetencje do wyznaczania rodzaju zadań i ich rozmiaru w poszczególnych województwach, powinien mieć również wiążący wpływ na wielkość przyznawanych publicznych środków finansowych na realizację tych zadań. Mimo wielu prób podejmowanych od 2002 r., przy okazji kolejnych nowelizacji Ustawy o ochronie roślin, nie udało się tego wadliwego podporządkowania zmienić. Powoduje to wiele komplikacji przy realizacji bieżącego nadzoru nad często dynamicznymi zmianami występowania organizmów szkodliwych w różnych częściach kraju, ale również utrudnia prowadzenie aktywnej polityki finansowania zadań inwestycyjnych Wojewódzkich Inspektoratów Ochrony Roślin i Nasiennictwa, np. laboratoriów badawczych, których prowadzenie jest bardzo kosztowne.
W ostatnich latach pojawiło się nowe zagrożenie dla funkcjonowania służby ochrony roślin, wynikające z wizji powołania urzędu o gigantycznych rozmiarach i strukturze trudnej do sprawnego zarządzania, mającym nadzorować bezpieczeństwo żywności. Koncepcje są różne, nowy urząd miałby powstać z połączenia od trzech do pięciu obecnych różnych urzędów, podległych wojewodom. Każda $\mathrm{z}$ tych koncepcji bardzo źle wpłynie na stan kadry służby ochrony roślin, która jak już wcześniej wspomniano, powinna posiadać bardzo specjalistyczną, ale interdyscyplinarną wiedzę. Obecnie bardzo trudno jest pozyskać odpowiednio przygotowanych absolwentów szkół wyższych, przydatnych w Inspekcji. Analiza materiałów z rekrutacji kandydatów do pracy w Wojewódzkich Inspektoratach Ochrony Roślin i Nasiennictwa, prowadzonej w oparciu o zasady ustalone ustawą o służbie cywilnej, pozwala na wyciągnięcie bardzo smutnych wniosków. Tylko nieco ponad 20\% kandydatów potrafi w sposób dostateczny identyfikować choroby roślin po specyficznych symptomach czy też rozróżniać podstawowe szkodniki o znaczeniu gospodarczym albo chwasty we wczesnych fazach rozwojowych. Jest to bardzo podstawowa wiedza, bez opanowania której nie można być inspektorem ochrony roślin, dokonującym lustracji zdrowotności upraw w gospodarstwie rolnym, nie mówiąc już o możliwości dokonania oceny zagrożenia fitosanitarnego czy też celowości wykonania zabiegu ochronnego. Trudno oczywiście wymagać od absolwentów szkół rolniczych specyficznej wiedzy z ochrony roślin na wysokim poziomie, bo to zadanie dla pracodawców ich zatrudniających, ale szkoły winny przygotować odpowiednie programy nauczania oraz egzekwować właściwą ich realizację. Aktualnie w PIORiN pracuje 2257 osób, $\mathrm{z}$ tego 1970 na stanowiskach merytorycznych (Informacja o realizacji zadań 2010 roku). W ostatnich latach bardzo wielu doświadczonych specjalistów ochrony roślin przeszło i przechodzi na zasłużone emerytury lub po 2-5 letnim okresie pracy i zdobyciu odpowiedniej wiedzy, rezygnuje $\mathrm{z}$ pracy $\mathrm{z}$ powodu niskich zarobków. Tylko w latach 2008-2010 z Inspekcji odeszło $318 \quad(16 \%$ zatrudnionych) pracowników - członków korpusu służby cywilnej. Rodzi to dodatkowe problemy dla wojewódzkich inspektoratów, które powinny zapewnić spore środki finansowe na specjalistyczne przygotowanie nowo zatrudnianych pracowników, albo poprzez udział w studiach podyplomowych, albo w specjalistycznych szkoleniach. Przygotowanie dobrego specjalisty ochrony roślin to proces długotrwały i kosztowny, zwłaszcza dla kiepsko finansowanych Wojewódzkich Inspektoratów Ochrony Roślin i Nasiennictwa, a tym bardziej dla bardzo nisko, a wręcz żenująco nisko wynagradzanych pracowników Inspekcji. Przez kilka ostatnich lat budżety wojewódzkich inspektoratów są ustalane na tym samym, a w niektórych przypadkach nawet na niższym poziomie z roku na rok. Sytuacja taka wymusza na wojewódzkich inspektorach likwidację części terenowych komórek organizacyjnych, które skupiają specjalistów pracujących bezpośrednio z producentami rolnymi. $\mathrm{Na}$ koniec 1999 roku (nowy podział administracyjny kraju), Inspekcja miała w swej strukturze 306 komórek terenowych w powiatach (delegatury i oddziały), a w roku 2011 już tylko 270. 
Oznacza to $12 \%$ spadek liczby struktur Inspekcji działających w powiatach. Jednocześnie co roku na Inspekcję nakładane są nowe ważne zadania i liczba realizowanych zadań wzrasta, co łatwo sprawdzić w rocznych sprawozdaniach $\mathrm{z}$ wykonania zadań, publikowanych przez Głównego Inspektora Ochrony Roślin i Nasiennictwa. Od wielu lat nie ulega podwyższeniu fundusz na wynagrodzenia pracowników i środki na finansowanie rozwoju zawodowego służby ochrony roślin. Na dowód prawdziwości tego warto też podać, że średnie miesięczne wynagrodzenie pracowników wojewódzkich inspektoratów w 2011 roku wynosiło 2377 PLN brutto (co netto daje zaledwie kwotę 1616 PLN), podczas, gdy średnie wynagrodzenie miesięczne w gospodarce narodowej w Polsce, w trzecim kwartale ubiegłego roku wyniosło 3416 PLN brutto (Komunikat Prezesa Głównego Urzędu Statystycznego M.P. Nr 103, poz. 1042). Pracownicy służby ochrony roślin osiagają zaledwie $70 \%$ (parytet) średniego wynagrodzenia $\mathrm{w}$ gospodarce kraju. Potwierdzeniem dramatycznie złej sytuacji płacowej w tej części sfery budżetowej jest fakt, że w związku ze zmiana przepisów o minimalnym wynagrodzeniu pracowników, $\mathrm{z}$ dniem 1 stycznia 2012 roku średnio około 10\% inspektorów (8-12\%), członków korpusu służby cywilnej uzyskiwało wynagrodzenie niższe, niż przewiduje prawo, czyli poniżej 1500 PLN miesięcznie brutto.

W takiej sytuacji finansowej trudno wymagać, aby pracodawcy dofinansowywali kształcenie młodych kadr, a tym bardziej niemoralne jest oczekiwanie, że młodzi pracownicy ze swoich głodowych pensji będą finansować specjalistyczne kształcenie w ochronie roślin. Podobnie trudna sytuacja finansowa i kadrowa panuje w państwowym doradztwie rolniczym. Sytuację szkoleniową młodych kadr ochrony roślin w wojewódzkich inspektoratach nieco łagodzą szkolenia wewnętrzne prowadzone przez doświadczonych, o wieloletnim stażu, pracowników ochrony roślin. To nie może zastapić jednak udziału pracowników w studiach podyplomowych, specjalistycznych szkoleniach zewnętrznych prowadzonych przez pracowników naukowych jednostek naukowo-badawczych, w tym Państwowych Instytutów Badawczych resortu rolnictwa. Dowodem coraz trudniejszej sytuacji w zdobywaniu wiedzy przekazywanej przez pracowników nauki, jest spadający z roku na rok udział pracowników wojewódzkich inspektoratów oraz służb doradczych w sesjach naukowych organizowanych przez Instytut Ochrony Roślin - Państwowy Instytut Badawczy czy konferencjach Instytutu Hodowli i Aklimatyzacji Roślin Państwowego Instytutu Badawczego dotyczących uprawy i ochrony ziemniaka, rośliny bardzo wrażliwej fitosanitarnie. Udział pracowników ochrony roślin w Sesjach Naukowych Instytutu Ochrony Roślin - Państwowego Instytutu Badawczego $\mathrm{w}$ ostatnich latach gwałtownie spada. Jeszcze w końcu lat 90. ubiegłego wieku każdego roku przyjeżdżało 250 do 300 osób, w latach 2005-2006 było to 70-80 osób, w roku 2010 - 39, a na obecną sesję zgłosiło się zaledwie 27 osób. Jeszcze gorzej sytuacja wygląda na konferencjach ochrony ziemniaka, organizowanych przez Instytut Hodowli i Aklimatyzacji Roślin Państwowy Instytut Badawczy, na których w ostatnich latach można było spotkać pojedyncze osoby i to tylko z niektórych wojewódzkich inspektoratów. Podobnie niezadawalający jest udział pracowników ochrony roślin w konferencjach naukowych, organizowanych przez Instytut Ogrodnictwa.

Bez wydatnego zwiększenia poziomu finansowania Inspekcji Ochrony Roślin i Nasiennictwa, trudne będzie zapewnienie właściwego nadzoru nad wdrożeniem i realizacją nowego prawa unijnego i krajowego, o którym była mowa $w$ tym referacie. Polska może mieć poważny problem z właściwym wdrożeniem integrowanej ochrony roślin, Krajowego Planu Działania oraz zapewnienia nadzoru nad bezpieczeństwem żywności, a także nadzoru nad produkcją roślin modyfikowanych genetycznie. Bez zwiększenia finansowania $\mathrm{i}$ właściwych zmian organizacyjnych, może powstać poważny problem ze swobodnym dostępem towarów pochodzenia roślinnego do rynku wspólnotowego i państw trzecich. Trudno bowiem oczekiwać, że lekarstwem na te bolączki będzie powstanie urzędu - molocha w postaci inspekcji bezpieczeństwa żywności.

\section{Podsumowanie / Summation}

Wybierając aktualne problemy ochrony roślin w Polsce skupiono się na tych nie tylko najważniejszych, ale również mających istotne znaczenie $\mathrm{w}$ przygotowaniu polskiej produkcji roślinnej do wprowadzania $\mathrm{z}$ dniem 1 stycznia 2014 roku integrowanej ochrony roślin i przy pełnym obiektywizmie, to w kilku przypadkach sytuacje należy ocenić jako poważną.

W zakresie ustawodawstwa należy mieć dużą nadzieję na wejście w życie, w 2012 roku Ustawy o środkach ochrony roślin oraz przyjęcie przez Rząd Krajowego Planu Działania. Nadal mało wiemy o będącej również w przygotowaniu Ustawie o ochronie roślin.

Uchwalenie Ustawy o środkach ochrony roślin oraz zatwierdzenie Krajowego Planu Działania nie tylko, że ukierunkuje dalsze działania w zakresie ochrony roślin w Polsce, ale także ureguluje zgodność polskiego prawa z Rozporządzeniem 1107 /2009 oraz Dyrektywą 2009/128/WE.

Zagadnienia nauki i edukacji zostały omówione w części I opracowania. Jako trudną należy uznać także potrzebę zmian programów nauczania oraz przygotowania szkoleń dla olbrzymich grup rolników. Będzie to duże wyzwanie, ale konieczne do podjęcia.

Dużo wysiłku kosztować będzie przygotowanie odpowiedniej liczby doradców w zakresie integrowanej ochrony roślin. Od kilkunastu już lat ochrona roślin odczuwa stały brak dobrze przygotowanych doradców, a obecnie ich wiedza musi być znacznie szersza. Rozstrzygnięcia wymaga umiejscowienie obserwacji nad stanem fitosanitarnym upraw. Jeżeli nastapi przeniesienie tego obowiązku do służb doradczych i samego rolnika, to natychmiast trzeba podjąć organizację szkoleń prowadzonych według nowego programu, a także zadbać o środki na zakup wyposażenia.

Szeroko omówiony w opracowaniu stan obecny i problemy Państwowej Inspekcji Ochrony Roślin i Nasiennictwa pozwalają na sformułowanie następującego ogólnego wniosku. Inspekcja odgrywająca rolę nadzorczą nad pra- 
widłowością stosowania środków ochrony roślin, ochroną kraju przed nowymi organizmami szkodliwymi i gwarantująca bezpieczeństwo konsumenta, ale i środowiska wymaga pilnego wsparcia etatowego, zabezpieczenia warunków rozwoju pracowników i ich godziwego wynagradzania. To bardzo ważne zadanie na najbliższe lata.

Cel jest jednak ważny i niedaleki.

W pierwszej części opracowania omówiono w zarysie rozwój ochrony roślin w Polsce po II Wojnie Światowej. Godny podkreślenia jest fakt, że polska ochrona roślin nie tylko, że nie popełniła błędu nadmiernej chemizacji, ale w wielu przypadkach, Uchwała Rady Ministrów Nr 64/70 i zapisy Ustawy o ochronie roślin z 1995 roku, zabezpieczając wymogi ochrony zdrowia ludzi oraz środowiska wyprzedzała podobne decyzje podejmowane w innych krajach. Zabezpieczenie wymaganych środków i koordy- nacja pozwoliły na udaną realizację badań naukowych, a zaangażowanie pracowników służby ochrony roślin gwarantowało prawidłową realizację praktycznej ochrony roślin. Działania te były zawsze wspierane przez pracowników administracji państwowej.

Obecnie przed ochroną piętrzą się nowe wyzwania wymagające olbrzymiego zaangażowania pracowników wszystkich instytucji związanych $\mathrm{z}$ ochroną roślin, ale i centralnych decyzji zabezpieczających realizację zamierzeń.

Integrowana ochrona roślin jest gwarantem uzyskiwania wysokich plonów o dobrej jakości, ale wymaga często od producenta większych nakładów i właściwego podejścia. Źle by się stało, gdyby wdrożenie integrowanej ochrony roślin miało charakter tylko formalny.

\section{Literatura / References}

Informacje o realizacji zadań przez Państwową Inspekcję Ochrony Roślin i Nasiennictwa w latach 2003 do 2010. GIORiN Warszawa, 156 ss.

Komunikat Prezesa Głównego Urzędu Statystycznego z dnia 10.11.2011 r. w sprawie przeciętnego wynagrodzenia w gospodarce narodowej w trzecim kwartale 2011 r. Monitor Polski Nr 103 z 2011 r., poz. 1042.

Piekarczyk K. 1961. Geneza, podstawy naukowe i zasady organizacyjne prognoz i sygnalizacji w Polsce. Biul. Inst. Ochr. Roślin 12: 301-328.

Pruszyński S., Walczak F. 2010. Monitoring agrofagów - podstawa integrowanej ochrony roślin. Zagadnienia Doradztwa Rolniczego 4 (10): 5-20.

Rzeźnicki B. 2012. Założenia krajowego planu działania na rzecz ograniczenia ryzyka związanego ze stosowaniem środków ochrony roślin na lata 2013-2017. s. 7-14. Materiały 55. Ogólnopolskiej Konferencji Ochrony Roślin Sadowniczych. Instytut Ogrodnictwa, Skierniewice, 15-16.02.2012, 87 ss.

Walczak F., Bandyk A., Jakubowska M., Roik K., Tratwal A., Złotkowski J., Heryng I., Gajewski M. oraz Inspektorzy Wojewódzkich Inspektoratów PIORiN. 2011. Nasilenie występowania niektórych chorób i szkodników roślin uprawnych w Polsce w roku 2010. Prog. Plant Prot./Post. Ochr. Roślin 51 (1): 133-152. 